\title{
THE EVOLUTION OF FOREIGN SECURED LENDING IN CHINA: SOCIALISM AND PROPERTY
}

\author{
MARC A. SOBEL* \\ and Danian Zhang $\ddagger$
}

\section{INTRODUCTION}

Ten years ago, the senior leader of the People's Republic of China ("PRC"), Deng Xiaoping, declared in the Third Plenum of the Eleventh Communist Party Central Committee that modernization would replace Chairman Mao's concept of political and class struggle as China's main objective. The Committee session set China on a course of economic reform. Since that time, the world has witnessed great changes in China, including the development of private entities, Sino-foreign joint ventures, and the introduction of Western capital, science, and technology. As a consequence, China has gradually moved away from its centrally controlled economy and has tried to introduce market economic mechanisms into its socialist system.

The desire for economic reform and development in China has led to an enormous need for foreign capital, in the form of both direct and indirect investment. According to official Chinese statistics, during the seven years from 1979 to 1985 , medium- and long-term foreign loans totalled $\$ 13.1$ billion. From 1979 to 1989 , direct foreign investment has reached $\$ 14.1$ billion, which led to the establishment of more than 22,000 Chinese foreign equity joint ventures, Chinese foreign contractual joint ventures, and wholly foreign-owned enterprises. In addition, China has involved foreign technology in more than 10,000 projects. $^{1}$

Foreign loans, among other vehicles, are important for infusing foreign capital investment in China. Many foreign banks are interested in becoming or have become, participants in the Chinese market. However, to most of the commercial lenders who have had bitter experiences with the Third World debt crisis, concerns are raised, justifiably, as to how they can secure loan repayment under the Chinese legal system; how they can obtain reliable guarantees from Chinese financial or non-financial institutions; what kind of

\footnotetext{
Copyright (C 1989 by Law and Contemporary Problems

* Senior Principal and General Counsel of Zell Partners, Ltd., a real estate consulting firm. Washington, D.C.

$\ddagger$ Attorney, Sidley \& Austin, Washington, D.C.

1. See People's Daily, October 27, 1989, at 1; China's Memorandum to GATT Contracting Parties, GATT L6125, Feb. 18, 1987.
} 
property can be used as collateral in secured transactions or project financings; and how their rights can be enforced under existing Chinese laws and regulations. This article discusses these issues and provides guidance for those unfamiliar with the Chinese system. While some of these issues cannot be fully explored due to the developing nature of Chinese law, the authors hope to shed light on the general principles of Chinese property law and to examine the evolution of foreign secured lending in China. Particular attention will be paid to the application of these laws and regulations to China's special economic zones and coastal open cities.

\section{II}

\section{Socialism and Property LaW}

The current legal system of the People's Republic of China has evolved from a foundation of traditional Chinese values tempered by a heady dose of Maoist and Marxist philosophy. The fundamental socialist underpinnings of Chinese society have been modified by the realities of governing a diverse developing country with a population of one billion people.

Traditional Marxism views law and legal theory as the handmaidens of a repressive state that should play no essential part in the make-up of the nature of social beings. ${ }^{2}$ Law and legal theory are seen as playing a transitional step in the formation of new social habits which would eventually make the need for a legal system unnecessary. The Marxist belief is that a revolution will give way to a dictatorship of the proletariat after a period of using laws to construct an egalitarian social order. ${ }^{3}$ Society would eventually have no need for laws since it would become self-regulated, if not completely unregulated. ${ }^{4}$

At the current time, socialist countries with strong Marxist foundations have not yet been able to reach the theoretical point where laws and legal systems are abandoned. On the contrary, countries such as China and the Soviet Union have developed legal systems replete with Codes, Statutes, and Proclamations. In order to reconcile the seeming conflict between the need for law in reality and the necessary abolition of law in theory, commentators on socialism have found a role for law in a socialist society by theorizing that law as an intellectual system actually consists of fundamental concepts and institutions that are sociologically neutral. It is a society's application of these concepts and institutions for its own purposes that determines whether social justice or inequity will exist. Thus, a socialist society with just ends can make use of neutral legal principles to promote the good of all people. The utility of this approach is that it accepts law as a given and shifts the theoretical discussion away from the necessity of law and towards the use of the legal system to control the means of production in society. Control of the means of production in turn means control of property.

2. Tay \& Kemenka, Marxism, Socialism and the Theory of Law, 23 Colum. J. Transnat'L L. 217 , 218 (1985).

3. Id. at 224 .

4. Id. 
The control of property in a socialist society has long been viewed as a key to the success of a socialist revolution. Private ownership of property (that is, property that constitutes the means of production) is to be abolished in favor of state ownership or ownership by the people. ${ }^{5}$ The emphasis in socialist theory has always been on control of property and not on the existence of an abstract legal concept of property that is value neutral. An evolution in the discussion of property has occurred that is a corollary to the changes in the theoretical role of legal systems in a socialist society, which is discussed above. The concept of property will not disappear due to a shift away from the emphasis on control and ownership. On the contrary, the view now is that the legal concept of property will remain necessary in any legal system. ${ }^{6}$ In the end, some person or entity has to be endowed with the power of control necessary for steering society and protecting both social and individual interests. ${ }^{7}$ This recent shift of discussion of the role of property is problematic in light of traditional Marxist theories of property.

The abolition of private ownership is viewed by Marx as a necessary precedent to the formation of a socialist order and economic power base. ${ }^{8}$ The transfer of property ownership from private to public hands is seen as a natural step in a social revolution intended to bring the working class to power. ${ }^{9}$ Public ownership is vital to ensuring that the means of production will be used for the good of the many rather than for the enrichment of a few.

Marxist theory aside, years of inefficient production have led some socialist nations, including China, to reexamine the place of private ownership or control in a society of state ownership. ${ }^{10}$ In order to reconcile the limited success of private ownership experiments with the theoretical underpinnings of socialism, adjustments have had to be made in socialist discussions of the role of property. Property, as discussed above, can now be viewed as a neutral proposition. It is recognized that all societies impose at least some limitations on what may be owned privately and on the use or disposition of private

5. Id. at 245. In the mid-1950's, Mao launched the massive Socialist Transformation Movement in China, the purpose of which was to implement his plan of public ownership under the socialist system on a large-scale basis. As a result of this movement, most of the private entities in China were merged with enterprises owned by the state.

6. Tay \& Kemenka, supra note 2, at 246

7. Id.

8. Butler, Marxian Concepts of Ownership in Soviet Law, 23 Colum. J. Transnat'L L. 281 (1985).

9. Id. at 286.

10. In April, 1988, the First Session of the Seventh National People's Congress adopted a constitutional amendment, which expressly provides for the legal rights and the legitimate existence of private enterprises in China. This legitimized the trend toward private enterprise which had developed over recent years. For instance, in Shanghai, one of the biggest industrial and commercial cities in China, there are at present more than 70,000 private enterprises engaging in business activities in various fields, such as industry, construction, transportation, mining, and services. In the countryside, China began its march away from Soviet-style socialism with the dismantling of the country-wide system of collective farming. Now throughout China, farmers may contract individual plots from collectively owned land to cultivate on a family basis. A percentage of the farmer's crop is contracted for purchase by the state, while the remainder can be sold on the free market. See People's Daily, Dec. I, 1988; see also Wash. Post, June 30, 1988, at A29. 
property." The question of control over private property thus becomes one of degree of ownership. Acceptable degrees of ownership are in turn enforced through a legal system.

In a socialist country, the critical threshold for permissible levels of private property ownership is less than that allowed in a capitalist society. ${ }^{12}$ The existence of a shifting threshold does not, however, fully reconcile the conflicts inherent between the socialist theory of state control of the means of production and the practical realities of increased productivity from limited private ownership of property. It is with this dichotomy between theory and reality in mind that we turn our discussion to property law in China and the recent Chinese regulations permitting collateralization of foreign loans.

\section{III}

\section{General Structure of the Chinese Legal System}

As a prerequisite to examining the detailed Chinese laws and regulations relating to property and secured lending, a basic knowledge of China's legal system is required.

As in most socialist countries, the laws in China are promulgated by a strong central governing body, in this case the National People's Congress and its Standing Committee. The Standing Committee also interprets statutes, and its findings have a binding effect on the courts. ${ }^{13}$ The People's Congresses and the Standing Committees of the provinces, the autonomous regions, ${ }^{14}$ and the special municipalities ${ }^{15}$ can promulgate laws and regulations to accommodate the special circumstances and needs of their own areas, provided that the laws and regulations are not inconsistent with the laws enacted by the National People's Congress and its Standing Committee. ${ }^{16}$ The State Council, a central government bureau, can enact detailed regulations to implement the relevant foreign investment laws adopted in the National People's Congress. ${ }^{17}$

China has a uniform court system that is responsible for enforcing the civil laws. According to the Organic Law of the People's Courts, there are three types of courts in China: (1) local people's courts; (2) military courts; and (3) the Supreme People's Court. ${ }^{18}$ Local people's courts are divided into basic

11. Butler, supra note 8 , at 291 .

12. Id. at 292.

13. Chinese Const. arts. 58, 62(1) \& (3), 67(2) \& (3).

14. Tibet, Xinjiang, Ningxia, Guangxi, and Inner Mongolia are autonomous regions in China.

15. Beijing, Shanghai, and Tianjin are special municipalities under the direct control of the central government.

16. Chinese Const. arts. 100, 116.

17. For example, the Law of the PRC on Joint Ventures Using Chinese and Foreign Investment was adopted on July 1, 1979, at the Second Session of the Fifth National People's Congress. On Sept. 20, 1983, the Regulations for the Implementation of the Law of the PRC on Joint Ventures Using Chinese and Foreign Investment were promulgated by the State Council. The power to interpret the regulations is vested with the Ministry of Foreign Economic Relations and Trade.

18. The Organic Law of the People's Court, art. 2. 
level people's courts, intermediate level people's courts and higher level people's courts.

Cases involving foreign elements would first be heard in the intermediate level people's court. ${ }^{19}$ An appeal to the higher court would be possible although the party would only be entitled to one appeal during the course of a case. The Supreme People's Court, the highest court of the land, hears first instance cases which have great influence throughout the country, as well as first instance cases that "it deems should be tried by itself."

Unlike the Anglo-American legal system, the courts in China follow the statutes as set forth and do not, in the common law sense of the concept, follow case precedent when issuing judgment in a dispute. Rather, courts apply statutes in the adjudication of cases and do not create binding law. However, many laws and regulations are broadly drafted to encompass the general principles and often do not include the mechanics necessary for complete enforcement of such principles. This is the problem faced when analyzing much of the legislation discussed in this article. However, the courts in China often find themselves enjoying some discretion when applying these broad principles to individual cases. The adjudications in these cases in turn influence other court decisions, although Chinese legal decisions are not usually publicly reported and are therefore unavailable for guidance. Similarly, guidelines set by the Supreme People's Court of the PRC or by the highest provincial people's courts are usually followed by the lower courts when deciding cases.

\section{IV}

\section{Loan Guarantees and their Limitations}

Since there was no clearly effective method of obtaining security for loans during the first wave of foreign lending in China in the late 1970's, foreign lenders often sought guarantees of indebtedness from the Bank of China or other Chinese financial and non-financial institutions. Guarantees were often forthcoming even though it was difficult for a foreign lender to determine whether the guaranteeing institution was sufficiently creditworthy. In order to slow the demand for these guarantees, in part because of a need to clarify credit requirements of guarantors and in part because institutions in China are decreasingly inclined to bear all financial risk in a transaction, the availability of loan guarantees has been tightened. ${ }^{20}$ In addition, in order to ensure the financial capability of a particular institution to act as a guarantor,

19. Article 17 of the Civil Procedure Law of the PRC provides that the intermediate people's court shall exercise jurisdiction over the trial of first instance cases involving a foreign element.

20. Problems arose with some ventures. In some cases, neither the projects concerned nor their foreign investors were able to service their debts. This failure left the banks with little choice other than to look to their guarantors. Recently, one syndicate started proceedings in Hong Kong against a Chinese guarantor. Commenting on this action, an official of the Guangdong Foreign Economic Relations and Trade Commission confirmed that, in the instant case, China recognizes the validity of the guarantee. However, he also pointed out that, first, it was considered unfair for the guarantor to bear all responsibility upon demise of the foreign investor, and that, second, some guarantees had 
regulations have been enacted to qualify such institutions to issue foreign exchange guarantees.

Under article 4 of the Provisional Measures for the Control of Foreign Exchange Guarantees Provided by the Institutions Within the PRC, issued by the People's Bank of China on February $20,1988,{ }^{21}$ institutions that may issue foreign exchange guarantees must meet the following requirements: (1) they shall be financial institutions with legal authorization to conduct foreign exchange guarantee business ${ }^{22}$ or (2) they shall be non-financial enterprises

not been properly arranged due to China's inexperience with foreign investment at the time. See Soutar, China's Foreign Guarantee and Capital Ratio Solution, INT'L FIN. L. REv., June, 1987, at 30, 31.

21. The People's Bank of China is the central bank of China.

22. There are banks and international trust and investment corporations authorized by the Chinese government agency in charge of exchange control to engage in the foreign exchange business. Until the end of March 1986, the following financial institutions had been permitted by the State Administration of Exchange Control to act as guarantors in dealing with foreign exchange business:

Banks:

1. The Bank of China and its branches;

2. The Investment Bank of China;

3. The Shanghai Branch of Overseas Chinese Banking Corporation L.td.

4. The Shanghai Branch of Standard Chartered Banking Corporation Lid

5. The Shanghai Branch of the Bank of East Asia Ltd;

6. The Shanghai Branch of the Hong Kong and Shanghai Banking Corporation;

7. The Shekou Branch of Nanyang Commercial Bank;

8. The Shenzhen Branch of Bank of Credit and Commerce International (Overseas) Ltd;

9. The Shenzhen Branch of Banque Indosuez;

10. The Shenzhen Branch of Guangdong Provincial Bank;

11. The Shenzhen Branch of Nanyang Commercial Bank;

12. The Shenzhen Branch of Societe Generale;

13. The Shenzhen Branch of Standard Chartered Bank;

14. The Shenzhen Branch of the Hongkong and Shanghai Banking Corporation;

15. The Xiamen Branch of Chiyu Banking Corporation Ltd;

16. Xiamen International Bank;

17. The Xiamen Branch of the Hongkong and Shanghai Banking Corporation;

18. The Xiamen Branch of United Overseas Bank;

19. The Zhuhai Branch of Nantong Bank;

International Trust \& Investment Corporations:

1. Anhui International Trust \& Investment Service Corporation;

2. The Bank of China Trust \& Consultancy Company;

3. Beijing International Trust \& Investment Corporation;

4. China International Trust \& Investment Corporation;

5. China Venturetech Investment Corporation;

6. Chongqing International Trust \& Investment Corporation;

7. The Commercial Bank of China Trust \& Investment Corporation;

8. Dalian International Trust \& Investment Corporation;

9. Fujian Investment \& Enterprise Corporation;

10. Guangdong International Trust \& Investment Corporation;

11. Guangxi International Trust \& Investment Corporation;

12. Guangzhou International Trust \& Investment Corporation;

13. Hebei International Trust \& Investment Corporation;

14. Henan International Trust \& Investment Corporation;

15. Hubei International Trust \& Investment Corporation;

16. Hunan International Trust \& Investment Corporation;

17. Jiangsu International Trust \& Investment Corporation;

18. Jiangxi International Trust \& Investment Corporation;

19. Jilin International Trust \& Investment Corporation;

20. Lian Yun Gang International Trust \& Investment Corporation;

21. Liaoning International Trust \& Investment Corporation; 
which are recognized legal entities with foreign exchange income, provided that the total amount of the liabilities guaranteed by the non-financial enterprise shall not exceed the amount of the foreign exchange funds possessed by such enterprise. The State Administration of Exchange Control ("SAEC") has confirmed that the reference to "foreign exchange funds possessed by the enterprise" means the foreign exchange allocated to the enterprise for use at its discretion, or distributed to the enterprise in the normal course of business. ${ }^{23}$

Further limits are also imposed on legally authorized financial institutions. Under article 4 , the sum of the guarantees and other foreign exchange liabilities of a financial institution shall not exceed twenty times the foreign exchange funds possessed by such an institution. SAEC has indicated that the term "foreign exchange funds possessed by such an institution" refers only to the funds directly owned or controlled by the institution. Funds deposited with the Bank of China by customers would not, therefore, be considered foreign exchange funds possessed by the Bank of China, thus further diminishing the amount of funds able to be guaranteed. ${ }^{24}$

In addition, the scope of a guarantee is similarly limited. First, with respect to a guarantee to a Chinese enterprise, while a guarantee may be issued to an enterprise that is registered under Chinese law, the guarantor is not permitted to guarantee the registered capital of such an enterprise. Furthermore, a guarantor may not provide a guarantee to any Chinese enterprise that is established outside of Chinese territory. This includes foreign corporations which are wholly owned subsidiaries of Chinese organizations. Guarantees will also not be provided to foreign institutions or enterprises involved in foreign investment in China, unless these institutions or enterprises can provide as collateral foreign exchange assets equal in value to the loan.

Article 13 of the Measures provides generally that the guarantor is entitled to request a security interest from a debtor and charge a given amount of guarantee fees commensurate with the risk of the loan. The guarantor itself should conduct a loan feasibility study to obtain accurate information on the

22. Nanjing International Trust \& Investment Corporation;

23. Ningxia Islam International Trust \& Investment Corporation;

24. Shanghai Investment \& Trust Corporation;

25. Shantou International Trust \& Investment Corporation:

26. Shanxi Economic Development \& Investment Corporation;

27. Shanxi Joint Financial Investment Corporation;

28. Shenyang International Trust \& Investment Corporation;

29. The Shenzhen Branch of Guangdong International Trust \& Investment Corporation;

30. Shenzhen International Trust \& Investment General Corporation

31. Sichuan Changjiang International Trust \& Investment Corporation;

32. Tianjing International Trust \& Investment Corporation;

33. Xiamen International Trust \& Investment Corporation.

34. Zhejiang International Trust \& Investment Corporation;

35. Zhongyuan Development Trust \& Investment General Corporation (Henan).

23. See Young, Foreign Exchange Guarantee - A Chinese Puzzle, INT'L FIN. L. REv., Apr. 1988, at 26, 27; see generally Soutar, supra note 20 , at 30.

24. Id. 
debtor's creditworthiness. A lender has the right under article 8 of the Measures to request relevant financial information from the guarantor, such as its financial report and balance of foreign exchange. After the guarantee is granted, the guarantor should continue to monitor the debtor's financial condition. The parameters of such supervision will be agreed upon by the debtor and the guarantor in their negotiated agreement. ${ }^{25}$

The rights, obligations, and duties of the guarantor and debtor are provided in articles 9 through 12 of the Measures. Certain basic principles similar to those of the common law are adopted and formalized. According to the provisions, any modification of or amendment to the underlying contract shall require consent from the guarantor, failing which the guarantor's obligation shall be discharged automatically. ${ }^{26}$ In addition, if the creditor fails to perform its obligations under the agreement, the guarantor's obligations shall also be released automatically. ${ }^{27}$ The guarantor, moreover, has the right to demand compensation for any damages it suffers by virtue of a breach by the debtor or the creditor. ${ }^{28}$ On the other hand, if the debtor fails to perform its obligations under the relevant loan agreement, the guarantor is required to fulfill its guarantee function. The guarantor, after performing its obligations, then has the right of recourse against the debtor to recover its damages. ${ }^{29}$ It should be reiterated that the legislative intent of the Measures is to provide that a guarantor's obligations are secondary only and conditional to those of the debtor. ${ }^{30}$

Subsequent regulations issued by the People's Bank of China impose further guarantee limitations on non-banking financial institutions, wholly owned foreign bank branches, and Chinese foreign joint venture banks in the Special Economic Zones. Under the Measures for the Control of the Foreign Exchange Business of Non-Banking Financial Institutions of October 1, 1987, the sum of the foreign exchange loans and the total foreign exchange guarantees provided by non-banking financial institutions to a single enterprise, whether inside or outside China, may not exceed 30 percent of the foreign exchange possessed by such institution. Similarly, the Provisional Regulations Relating to the Administration of the Business of Foreign Banks and Chinese Foreign Joint Venture Banks in the Special Economic Zones, enacted on June 17, 1987, provide that the aggregate amount of foreign exchange loans and foreign exchange guarantees provided by a foreign bank branch or a Chinese foreign joint venture bank to a single enterprise, whether inside or outside of China, may not exceed 30 percent of the total of the paidin foreign capital plus the foreign exchange reserve fund of the bank.

25. Provisional Measures for the Control of Foreign Exchange Guarantee Provided by Institutions Within the PRC, arts. 6 \& 8 .

26. Id. art. 9 .

27. Id. art. 11

28. Id. art. 11

29. Id. art. 10.

30. See Young, supra note 23. 
The large demand for foreign loans in China and limited availability of credit guarantees by Chinese financial or non-financial institutions have caused foreign lenders, desirous of conducting business in China, to look for other forms of security. For most commercial lenders, this has led to creativity in seeking further security for their loans. This, in turn, has led to the introduction of secured financing and project financing techniques.

\section{V \\ Project Finance}

The first widely used method for collateralizing foreign loans in China was project finance. Project finance is a technique developed by bankers and their counsel as a way of minimizing the risks that any one party in a transaction must bear. ${ }^{31}$ Historically, project finance has its roots in the aftermath of the mid-1970's oil crisis and recession. Bankers who sustained losses owing to escalating loan defaults and under-collateralization realized that future lending would require a greater exercise of caution. ${ }^{32}$ At the same time, many non-oil-producing lesser developed countries ("LDC") were finding it necessary to obtain commercial loans as a result of oil-related deficits, the worldwide recession, and declining terms of trade. ${ }^{33}$ In order to satisfy the demand of the LDC's and at the same time use conservative lending judgment, bankers concentrated on the possibility of directing loans towards specific development (usually production-oriented) projects. These projects, they reasoned, could be evaluated in advance to ensure that their success could cover the repayment of such a directed loan.

Bankers concluded that such a project-oriented approach would reduce the problems involved with traditional lending. First, lenders could focus their credit and risk analysis on a relatively discrete entity. Second, by negotiating for controls over the project during the loan negotiation process, mismanagement of the project could be reduced. Third, if a project was income-producing, a bank could look specifically to a source of cash flow to service its loan. ${ }^{34}$ In addition, project financing offers a significant advantage for the borrower because such loans are made available on a limited recourse basis, meaning that the sponsors of the project are not themselves responsible for the repayment of the project debt from their general assets. Also, since project financings are viewed as relatively secure transactions, a borrower is able to leverage favorably the amount of debt it can receive against the amount of its equity investment, usually up to as much as 75 percent of the cost. ${ }^{35}$

31. Rauner \& Stewart, Project Finance: A Risk Spreading Approach to the Commercial Financing of Economic Development, 24 HaRv. INT'L L.J. 145 (1983).

32. Id. at 148 .

33. Id. at 150 .

34. Id. al 151 .

35. Miller, Project Financing in China 270 (1986) (paper submitted to Shanghai International Investment Conference). 
The perceived advantages of these financings have often been borne out in practice, leading to an accepted definition of project finance. Project finance is defined as the "financing of a particular economic unit in which a lender is satisfied to look initially to the cash flows and earnings of that unit as the source of funds from which a loan will be repaid and to the assets of the economic unit as collateral for the loan."36

The key to the success of the project finance technique has been the lender's concentration on a reduction of its risk by enhancing the credit of a particular project. The most basic determination a lender must make is ascertaining the viability of the project itself. The completed project, for example, a plant or mine, must be able to generate adequate cash flow to meet internal needs, provide for unexpected contingencies, and still pay off debt. In addition, a market must exist for the products produced by the project, the management of the project must be experienced enough to successfully operate a complex production system or hire outside expertise, the host country itself must have the political stability and economic infrastructure necessary for ensuring the basic success of the project, and insurance coverage adequate to comply with cost projections must be available during all phases of the project. The project must also be backed by strong credit, and perhaps most importantly, the facilities, materials, and physical assets of the project must have some value in themselves.

Risk-spreading techniques are often used by lenders to decrease the credit burden of a project. The first level of lender protection lies in the debt coverage ratio the project has been able to negotiate with the borrower. Lenders make a loan on which their profit is limited. Interest margins are set in advance, and the lender's profit is measured by the difference between the interest earned and its cost of funds. The project's sponsors generally retain the up-side benefits of increased profit if the project succeeds. Lenders, therefore, feel that their down-side risk should be reduced by requiring that the amount of cash available for servicing the debt exceed the actual debt service by a safety factor. Ratios of two to one or more are often used. ${ }^{37}$

The second level of protection lies in the use of guarantees. These guarantees by the government of the host country or some semi-official entity, unlike payment guarantees discussed above, are often used to ensure the completion of the project itself. A 75 percent finished plant is worth less than 75 percent of a completed project. Similarly, guarantees of completion of necessary infrastructure are extremely useful to ensure that raw materials can be brought to the project and that the products can be adequately transported to the markets. For example, modern harbor and rail facilities should exist to assist with efficient distribution of the products.

Price support guarantees for the product, user guarantees for purchasing output (for example, take or pay contracts), guarantees of debt service

36. Rauner \& Stewart, supra note 31 , at 155.

37. Miller, supra note 35 . 
payment, and guarantees of the debt itself (similar to those discussed above) are other techniques for reducing a borrower's risk of default on a project finance transaction. ${ }^{38}$

Project finance, in spite of its innovative technique, is still basically a form of secured lending. The existence of valuable security, in the form of the physical assets of the project or the economic benefits that flow from them, reduces the potential losses for a lender. If the project fails, at least some value can be salvaged.

A secured position in a project benefits the lender in at least three ways. First, a security interest generally entitles the lender to realize on the collateral and become the owner of the project after a default. Though the lender will rarely desire to own the project, this right grants the lender leverage in its negotiations with the borrower during times of difficulty.

Second, the security interest grants the lender a preferred status and protects it from claims of the creditors. The proceeds of any liquidation of the project would flow to the lender with any remainder divided among subordinate creditors.

Third, the project could be liquidated and the loan perhaps repaid out of the proceeds. Liquidation is obviously a worst case scenario since an operating project would be more likely to yield a full repayment of the loan. ${ }^{39}$

The creation of security interests in the project is a precondition for the lender's being able to benefit from the secured lending. In China, at the present time, there is not any formal mechanism for the creation of security interests other than the limited provisions relating to real property discussed below. In addition, for the borrower to grant a security interest in the project, it must own the property and have the rights under Chinese law to grant such an interest. This would most likely involve obtaining some form of government approval. ${ }^{40}$

Another problem involves the concept of perfection of a security interest. Perfection describes the relation of the security interest to claims of third parties. In the United States, a system of recording and filing ensures perfection of an interest and protects against competing claims to the collateral. Similarly, the order of filing and recording determines the priority of any competing liens. If the lender's interest is filed first, no other creditor can claim superior rights; and a subsequent foreclosure by the lender will eliminate all junior liens from the collateral. In China, however, no formal system for determining priority of liens exists, except in very limited cases. ${ }^{41}$

In light of the paucity of Chinese legal guidance in the area of security interests, other methods are suggested for securing the lender's position. In cases where laws governing liens are nonexistent, creative lenders cause borrowers to transfer title in the collateral to a security agent acting for the

38. See generally Rauner \& Stewart, supra note 31, at 165-71

39. Miller, supra note 35 , at 275.

40. Id.

41. Id. 
lender. The borrower would continue to use the assets as if it owned them, though in the case of a default, the agent will transfer the property to the lender. If all obligations of the borrower are fulfilled, the property will be transferred back to the borrower at the end of a specific term. ${ }^{42}$

Another method of securing the loan, in the absence of a formal recording system, is to have the borrower assign its rights in various construction contracts, supply contracts, and operating agreements to the lender. The other parties to the contracts would be required to acknowledge the assignment and agree to perform their obligations for the benefit of the lender. If the borrower has not defaulted by the end of a given term, the contracts will be reassigned to it. ${ }^{43}$

Another type of security interest could be obtained in the proceeds from the sale of products or output of the project. The borrower could be required to deposit the proceeds at a specific bank which would in turn agree to pay the sums to the lender if a default has occurred. As with the other methods, the arrangement would be terminated if no default has occurred by the end of a given time. If the output from the project is to be exported from China, this arrangement could be made with deposits in a bank outside of China.

The theoretical bases for project finance lending are relatively straightforward. However, in practice, the utilization of various levels of risk assessment and risk-spreading techniques coupled with the inherent problems of doing business in a lesser developed country can create a highly complicated final structure. The most effective way to illustrate the potential complexities of a project finance transaction is to examine an actual case study involving a highly ambitious mining venture undertaken by Occidental Petroleum Corporation in China. The case study demonstrates the difficulties inherent in utilizing the project finance technique in China, as well as the creativity needed to reduce lenders' risks in what is claimed to be the largest joint venture project in China. It is also the first major international financing on a limited recourse basis to take place in China. ${ }^{44}$

\section{VI}

The An Tai Bao Mining Project: A Case Study

The An Tai Bao Mine is located 230 miles west of Beijing. It is an open pit mine producing approximately fifteen million tons of washed coal a year, of which approximately nine million tons is of export quality with the remainder being earmarked for use by Chinese domestic power plants. The overall coal reserve of the mine is estimated to be approximately 450 million tons of good quality steam coal.

42. Miller, supra note 35 , at 276 ; although this method is theoretically sound as a means of securing lending, it has not been tested under Chinese law to this date.

43. $I d$.

44. J.J. Dorgan, Address Presented at East-West Conference 2 (Sept. 27, 1987). 
A joint venture structure was agreed upon in order to satisfy the demands of the Chinese that it be a partner in the project and in order to ensure that the financing would not appear on the balance sheet of the joint venturer. The latter was accomplished under American accounting rules by bringing the Chinese in as a 50 percent partner in the venture. A cooperative joint venture was set up between Island Creek of China Coal ("ICCC"), ${ }^{45}$ which is an operating company affiliate of the Occidental Petroleum Corporation, and Ping Shuo First Coal Company ("PSFCC"), which is a subsidiary of the China National Coal Development Corporation, which in turn is a subsidiary of the Chinese Coal Ministry. ICCC and PSFCC are entitled to equal shares of the coal and the profits from the mine. The joint venture was established by contract but is not considered an independent Chinese legal entity. Under Chinese law, a cooperative joint venture, of which the An Tai Bao venture is a prime example, may not be considered to have the same legal status as does an equity joint venture.

ICCC contributed approximately $\$ 400$ million to the joint venture. The Chinese partner's contribution is difficult to measure, though its investment in the mine and direct support facilities is probably close to $\$ 250$ million. This does not, however, include the value of creating a village for 17,000 workers and families, nor does it include the improvements at the port of Qing Huang Dao or railroad improvements near the project. Taking everything into account, the total investment in the project is over one billion dollars.

The structure for managing the project reflects the contributions of the partners and the desire of the Americans to control and oversee the mine in its initial years. Forty-five expatriate managers will operate the mine, each assisted by a Chinese deputy. For the first twelve years of operation, the ICCC people will be the managers. For the next eighteen years, the PSFCC deputies will take over as managers and the ICCC people will become their deputies.

Export sales of coal from the project will be handled by an agency of the coal ministry, China National Coal Import \& Export Corporation. It has an exclusive sales agency for twelve years to sell all of the ICCC coal and all PSFCC export coal.

The An Tai Bao joint venture financing is set up to become a limited recourse loan upon completion of the mine. There is no guarantee from the parent corporation or from the Bank of China, although certain guarantees, as discussed herein, do exist. ${ }^{46}$

A loan of $\$ 475$ million was advanced by a syndicate of international banks led by Bank of America, the Royal Bank of Canada, the Industrial Bank of

45. ICCC is owned equally by Occidental Petroleum Corporation and Bank of China Trust and Consulting Company ("BOCTC"). This arrangement accomplishes the goal of including the Chinese in the project while keeping the financing as an off-balance sheet transaction.

46. See supra Part IV. 
Japan, Credit Lyonnais, and Bank of China. Thirty-four additional banks were included in the consortium of lenders.

An Tai Bao Project

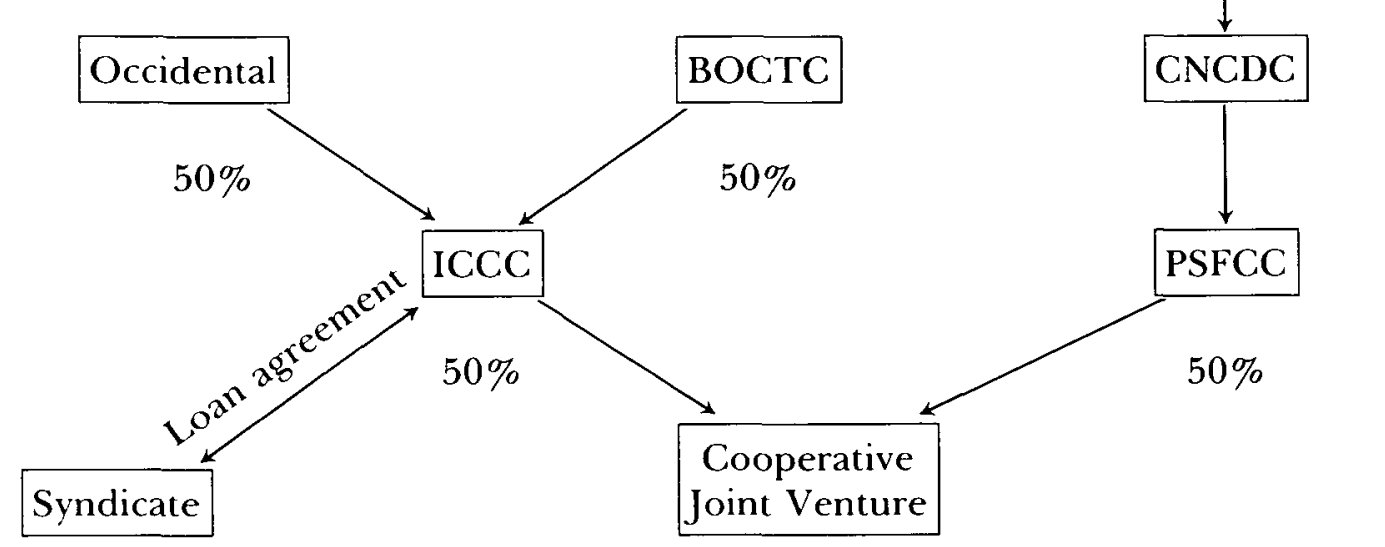

The $\$ 475$ million loan was divided into four facilities, A,B,C, and D, for purposes of risk reduction. Facilities $\mathrm{A}$ and $\mathrm{B}$ are supported by the sponsors (in the form of a guarantee) until completion of the project. At that time, the loan will become project supported, and the sponsors' direct responsibility will end. Facility $\mathrm{C}$ will remain guaranteed by the sponsors.

The guarantees for the first three facilities will also remain in place until the completion of the project. The sponsors have agreed to have the mine operating at a designated capacity for ninety-one consecutive days as a measure of completion. In addition, the railroad and port infrastructure must by such time be functioning properly because storage capacity for the coal is very limited. If the project is unable to function for eight continuous days after the ninety-one-day period, the mine would need to be shut down, and a default would exist in the completion requirement.

After the completion test is met, approximately $\$ 300$ million of the loan will become limited recourse. Another $\$ 100$ million will become limited recourse only after the price of coal reaches an agreed-upon price. Facility D is set up as a $\$ 75$ million stand-by credit loan. It can be drawn down, if necessary, to service project supported debt. This facility is guaranteed by the sponsors and is required to be repaid in full within twelve years. Owing to the limited recourse nature of this project finance transaction, the lenders also look to security interests in the project to enhance the credit of the loan, which complicates the loan arrangement greatly. Since the loan agreement and security agreement are not publicly available, we have no means of 
confirming the nature of the lender's security interests. However, the following arrangements were likely agreed upon. ${ }^{47}$

\section{A. Exploitation Rights in the Mine}

The first issue in the An Tai Bao Project is whether the foreign partner in the joint venture is vested with the rights to exploit the products of the mine, and if so, whether such rights are allowed under Chinese law to be transferred to lenders as collateral. Under article 71 of the General Principles, the ownership of a mine, like ownership of real property, is composed of four specific rights, namely, the rights of possession, use, benefit, and disposition. ${ }^{48}$ Although these four elements may be possessed separately, ownership is incomplete without them all. A person who is granted exploitation rights in a mine under Chinese law enjoys only the rights of use and benefit, and therefore lacks ownership.

Article 9 of the Chinese Constitution expressly provides that natural resources such as mireral resources and water, forests, woods, mountain land, grassland, undeveloped land and shorelines, are owned by the state, that is, owned by all of the Chinese people, ${ }^{49}$ except for those resources which are owned by collective organizations under the provisions of law. State-owned mineral resources are permitted to be exploited by state-owned enterprises or by collectively owned enterprises though exploitation by citizens is also permitted according to law. These lawful exploitation rights are protected and regulated by the state. ${ }^{50}$

In the An Tai Bao Project, the Chinese Ministry of Foreign Economics Relations and Trade ("MOFERT") argued that the exploitation rights in a coal mine were granted only to the Chinese partner, not the foreign partner. The foreign partner in the joint venture was granted only the limited rights of "participation in exploitation." In addition, the exploitation rights here are not evaluated and used as part of the Chinese investment. MOFERT contended, therefore, that ICCC was not entitled to transfer the exploitation rights to any third party. This caused problems for both ICCC and its lenders because without approval by MOFERT, it was impossible to enter into a useful security agreement.

After several rounds of negotiation, a compromise was finally reached under which ICCC may assign its rights of "participation in exploitation" in the mine to its lenders as collateral. In the event of a default, a third party may step into the debtor's position, but only if it has been approved by MOFERT. In addition, the Chinese partner in the joint venture has a right of

47. This information has been pieced together through conversations with attorneys for parties to the agreement, but is unconfirmed.

48. These components of ownership are very important in the discussion on land-use rights in Part VIII.

49. Cf. Epstein, The Theoretical System of Property Rights in China's General Principles of Civil Law, Law \& Contemp. Probs., Spring 1989, at 177.

50. See General Principles of Civil Law of the People's Republic of China ("General Principles"), art. 81. 
first refusal to purchase such rights in the event that the rights of the defaulting party are offered for sale to a third party.

\section{B. Products and Contract Rights}

The products (coal) of the venture belonging to ICCC were to be used as collateral for the loan. In addition, the proceeds of the take or pay contract entered into by the purchasers of the products were also assigned to the lenders as were, most likely, ICCC's contract rights themselves.

\section{Machinery and Equipment}

Machinery and equipment used at the mine are not used as loan collateral, since the lenders felt that enforcement in the event of a default would be very difficult under Chinese law.

The An Tai Bao project case study illustrates well the creativity required of foreign lenders and investors who seek security for the repayment of loans and capital investments in China. Such creativity has been a prerequisite to gaining adequate security, since the more straightforward Anglo-American legal concepts of a mortgage or other similar land rights interests were until recently not recognized in China. Given the socialist underpinnings of Chinese law and the related limitations on the concept of property ownership, the recent developments leading to the ability of a foreigner to gain rights in land (not ownership) are revolutionary. The new laws have also served to encourage property development activity, an area in which the productionoriented project finance method has not proven successful.

\section{VII}

\section{Chinese Property Law \& Security Interests}

Prior to examining the recent evolution in Chinese property law, a brief overview is useful. The principles of Chinese property law are broadly outlined in the Chinese Constitution. The General Principles of Civil Law follow these general principles and establish rules concerning property ownership and other property rights. ${ }^{51}$

As discussed above, the General Principles defines the concept of property ownership as being composed of four distinctive rights. These are the rights to possess, use, benefit from, and dispose of such property. ${ }^{52}$ Where property is acquired by contract or other lawful means, ownership is transferred at the time the property is delivered, unless the law or the contract of the parties provides otherwise. Consistent with socialist theory, state property belongs to all the people. Similarly, the property of collective organizations belongs to such collectives and includes (1) land, forests, mountains, grassland,

51. The General Principles was adopted by the Fourth Session of the Sixth National People's Congress on Apr. 12, 1986.

52. General Principles, art. 71 
undeveloped land, and shorelines designated by the law as collectively owned; (2) property of collective economic organizations; (3) collectively owned buildings, reservoirs, agricultural irrigation facilities, and educational, scientific, cultural, public health, sports, and other such facilities; and (4) other collectively owned property.

A citizen's personal property includes her lawful income, house, savings, personal articles used in daily life, trees, livestock and so on, and means of production which may be owned by citizens within the limits of the law. The right to own personal property, like the other property described above, is protected by law. However, the articles of the General Principles concerning protection of state-owned property, collectively owned property, and citizen's personal property are worded differently in terms of degree of protection. State property is "holy and inviolate," while collective property and "lawful property" of citizens are "protected by law." Apparently, state-owned property is accorded the highest legal status whereas protection for property of individuals extends only to that which is "lawful." This distinction may have implications where the property interests of the state, collective, and individuals are in conflict. In any case, the practical significance of these provisions is much alleviated by the basic principle of the General Principles that all the civil law subjects, including a state agency, a collectively owned organization, and an individual are accorded equal status under the law in civil transactions. ${ }^{53}$

The General Principles, which became effective on January 1, 1987, provides that a debtor or a third party may use its property as collateral for a mortgage. A mortgage is defined as a legal act in which a debtor or a third party provides certain property to a creditor for the purpose of securing the payment of the debt. ${ }^{54}$ When the mortgagor fails to perform its obligations, the mortgagee is granted a priority right in accordance with the provisions of law to value the collateral and credit it against the obligation, or to sell the collateral in order to obtain compensation from the proceeds. ${ }^{55}$ However, it must be remembered that under the Chinese system, a mortgage cannot be granted on land, since land cannot be owned by anyone other than the state. Therefore, a mortgage granted on a building may yield rights of ownership in the building without concomitant rights in the underlying land. Nor does Chinese law specify what type of property can be used as collateral or create a central registry of liens for the filing of mortgages. The law also fails to specify whether and how the state-owned or collectively owned enterprises can use their property as collateral and what the procedure is for the creation and enforcement of such interests.

Notwithstanding the fact that China still lacks encompassing national legislation in these respects, mortgage loan transactions have often been conducted in China, especially in Special Economic Zones and coastal open

53. Zheng, China's New Civil Law, 34 Am. J. Comp. L. 695 (1986).

54. Chinese EnCyclopedia 163, Vol. of Law \& Politics.

55. General Principles, art. 89. 
cities. In response to this practice, local laws and regulations have been enacted to accommodate the special circumstances and needs of these locales and to attract foreign investors and lenders who would insist upon collateralization of their loans. For example, in December, 1985, the Guangdong Provincial People's Congress issued the Regulations on Mortgage Loan Administration in Shenzhen Special Economic Zone to govern mortgage transactions in that Hong Kong border area. The Regulations were the first issued locally in China and are applicable to mortgage loan transactions between the banks and other financial institutions established in the Shenzhen Special Economic Zone, and Chinese foreign equity joint ventures, Chinese foreign cooperative joint ventures, wholly foreign-owned enterprises, and individuals. ${ }^{56}$

Under the Shenzhen Regulations, buildings and other non-real property goods and materials, securities, certificates of payment, and other rights, such as equity shares in the venture, contract rights to the products, etc., can all be used as mortgage collateral for a loan. ${ }^{57}$ According to the Regulations, a written contract shall be entered into between the mortgagor and mortgagee governing and describing the mortgaged property, copies of which shall be publicly filed to serve as notice to other lienors and shall be available for examination by financial institutions, companies, enterprises, and individuals. The mortgagor, without obtaining consent from the mortgagee, is not permitted to lease, sell, transfer, or further mortgage the collateral and any such action shall be deemed invalid. ${ }^{58}$

In case the debtor fails to repay the principal and interest when the loan agreement becomes due, the mortgagee is entitled to dispose of the mortgaged property. ${ }^{59}$ The mortgagee can dispose of the collateral by the following means: (1) it can sell a building and other material through auction (the concept of judicial foreclosure does not exist), and (2) it can transfer securities, certificates of payment, and other contract rights in accordance with the relevant provisions of the Regulations. ${ }^{60}$

If an auction is utilized, the mortgagee shall be responsible for obtaining a certificate of approval for such auction from the Registry where the original documents are filed. The auction will be conducted by the auction agency designated by the Shenzhen Municipal Government ${ }^{61}$ and the proceeds shall be distributed in the following order: first, to pay a service fee to the auction agency; second, to pay any taxes due on the collateral; third, to pay any outstanding principal and interest due on the debt; and fourth, the remainder, if any, to the mortgagor. ${ }^{62}$ Though the auction system and the division of proceeds appear similar to some Anglo-American foreclosure procedures, the

56. Regulations on Mortgage Loan Administration in Shenzhen Special Economic Zone, art. 2.

57. Id. art. 5 .

58. Id. art. 18.

59. Id. art. 22.

60. Id. art. 23.

61. Id. art. 24.

62. Id. art. 26. 
Shenzhen system lacks judicial safeguards and other common law mechanisms, such as equity of redemption, that protect a mortgagor in a contested proceeding.

It should be noted that the Bank of China has also adopted the concept of mortgage lending. Article 16 of the Measures on Bank of China's Loans to Foreign Investment Enterprises, published on April 7, 1987, provides that foreign investment enterprises in China may use their properties and rights as collateral to secure the repayment of principal and interest on a loan made by the Bank of China. Under the Bank Regulations, security interests may be granted in the following items of collateral: (1) buildings and machinery; (2) merchantable commodities in stock; (3) cash deposits or certificates of foreign exchange; (4) convertible securities, bonds, and debentures; and (5) shares of stock and other transferable rights. According to Chinese bank officials, mortgage loan practices will first be utilized with foreign investment enterprises, collectively owned enterprises, and private businesses before they are extended to state-owned enterprises. ${ }^{63}$

\section{VIII}

\section{LAND OWNERSHIP AND LAND-USE RightS}

As discussed above, land in China is either state-owned or collectively owned since Chinese law does not recognize private ownership. Article 2 of the Law of the PRC on Land Management provides that China "practices the socialist public ownership of land, which is ownership by the whole people and collective ownership by the working people. No unit or individual may appropriate, buy, sell, lease, or use any other method to illegally transfer land." 64 Generally, land in urban areas is state-owned and land in rural areas is collectively owned. State-owned land may be used in accordance with law by state-owned units or may be allocated for use by collective units. The state protects the rights of such units to use the land and benefit therefrom. In the interim, the units which use the land are under a duty to manage, protect, and make reasonable use of the land, ${ }^{65}$ a concept similar to the Anglo-American common law notion of a leasehold occupant's duty not to commit waste on property. In rural areas, peasants may be granted a plot of land for family use and benefit, but their interests fall short of satisfying the four requirements for ownership and therefore do not diminish the state's rights to such land.

If land has been purchased, sold, leased, or transferred by illegal means, any illicit gains shall be confiscated and within a limited period of time, buildings and other facilities newly built on the land shall be dismantled and

63. In Shenyang, the capital of Liaoning Province, a factory (Shenyang Acetylene Cylinder Plant) was given a 500,000 yuan loan in 1986 after it used a bus, 200 cons of steel, and ireasury bonds as collateral. The Shenyang branch of the Construction Bank of China will dispose of the collateral if the loan is not repaid when due. FBIS Daily Report, China, Sept. 12, 1986, at S2.

64. Law of the PRC on Land Management, art. 2, adopted on June 25, 1986, at the 16th Session of the Standing Committee of the Sixth National People's Congress [hereinafter Land Management].

65. General Principles, art. 80. 
removed or confiscated. In addition, fines and disciplinary action may be imposed upon those responsible for the illegal activity by their employment unit or a higher level authority. ${ }^{66}$

Recently, in order to bolster foreign investment in local development and to encourage foreign lending for such projects, a number of specialized localities have creatively worked within the Chinese concept of ownership to venture beyond building mortgages to permit the assignment of land-use rights. In addition to permitting a new type of collateral, assigned land-use rights permit a lender to transcend the limitations of a building mortgage to secure rights in land.

Under general Chinese law, if no regulations governing the compensated transfer of land-use rights have been adopted locally, any Chinese foreign joint venture requiring the use of a site for its project may file an application with the local department of the municipal or county government in charge of land and obtain the right to use a site, after securing approval and signing a contract. However, the joint venture that is permitted to use a site will be granted a right only to use the property, not to own it. In addition, this right of use is severely restricted and cannot be transferred to a third party. ${ }^{67}$

These national provisions governing land and restricting its transferability in any form and by any means have been felt by many business enterprises to be too stringent, particularly in coastal areas and special economic zones where international business practices are often followed. In order to recognize the changing circumstances surrounding increased foreign investment and development, the First Session of the Seventh National People's Congress adopted a constitutional amendment on April 13, 1988, which limits the state's monopoly on land by permitting individuals and entities to acquire and transfer land-use rights for compensation. This amendment and the recent measures adopted in Shanghai, Shenzhen, and Hainan are regarded as breakthroughs in the development of China's property law.

\section{A. Compensated Granting of Land-Use Rights}

Recently, the local governments in Shanghai, Shenzhen, and Hainan have issued regulations governing the compensated granting and transfer of landuse rights. These rights resemble the Anglo-American ground lease, where rights to construct improvements owned by a lessee are permitted on land, the ownership of which remains with the lessor. The following discussion is based mainly on the Measures of the Shanghai Municipality on Compensated Transfer of Land-Use Rights, the most sweeping and complete of the new legislation. 68 (See Appendix.)

66. Land Management Law, art. 47.

67. Law of the PRC on Joint Ventures Using Chinese and Foreign Investment, arts. 47, 53.

68. Measures of Shanghai Municipality on Compensated Transfer of Land-Use Rights was promulgated by the Shanghai Municipal Government on Nov. 29, 1987, and became effective on Jan. 1, 1988 [hereinafter Shanghai Measures]. 
Under the Shanghai Measures, the compensated granting of land-use rights is defined to mean the granting by the Municipal Government to a grantee of rights to use a specified piece of state-owned land for development and business purposes in return for a granting fee and land-use fee ("granting contract"). ${ }^{69}$ The conditions surrounding the grant, including the location of the land and the terms and conditions of the granting shall be collectively determined by the Shanghai Land Administration Bureau ("Land Bureau"), Shanghai City Planning and Construction Administration Bureau ("Planning Bureau"), and the Shanghai Real Estate Administration Bureau ("Real Estate Bureau"), and shall be implemented after being approved by the Municipal Government.

A "grantee" is broadly defined in the Measures to refer to those enterprises, and to other economic organizations or individuals, which are entitled to receive land-use rights by way of grant, transfer, or inheritance. A grantee can be either a domestic or foreign entity or individual, except for those entities or individuals from countries or regions which do not have diplomatic relations with China or have not set up any commercial representative office in China.

The Measures permit a subsequent assignment of such rights to a third party by means of a "compensated transfer of land-use rights." Consistent with the Chinese theories of property ownership, during the term of such compensated granting or transfer of land-use rights, the ownership of the land remains with the grantor. In addition, natural resources, minerals, and other buried or hidden objects under the land are excluded from the scope of any land-use rights transfer or granting. ${ }^{70}$

In Shanghai, the responsible authority in charge of the compensated granting and transfer of land-use rights is the Land Bureau. The Shanghai Measures require any contract granting land-use rights to be entered into directly between the Land Bureau and the grantee of such rights. The Land Bureau may grant land-use rights by means of a bilateral agreement or by an invitation to tender bids. ${ }^{71}$ The Measures set forth the specific procedure which must be followed for granting land-use rights by agreement between the Land Bureau and the grantee. The Land Bureau is required to provide any prospective land-use rights grantee with necessary information and relevant provisions relating to the designated land. After obtaining these materials, the prospective grantee shall submit to the Land Bureau, within the specified time, the land development and construction plan and documents relating to its ability to pay a granting fee. After receiving all required documents, the Land Bureau is required to respond to the prospective grantee within thirty days. After agreement is reached through negotiation, the Land Bureau and the grantee shall enter into a granting contract and the

69. Id. art. 2.

70. Id. art. 3.

71. In Shenzhen, the local government has the additional flexibility to grant land-use rights through a public auction. 
grantee must pay a granting fee in accordance with such contract. Finally, the grantee must obtain a land-use certificate from the Land Bureau and register the land-use rights in the Municipal Registry within the specified time. ${ }^{72}$ Registration is intended to be a safeguard for those seeking to place the public on notice of the granted rights, though the actual efficacy of the registration system has yet to be tested in practice in China (that is, resolving competing claims).

The procedure for granting land-use rights through tendering is also provided in the Shanghai Measures: (1) pursuant to the specific requirements related to the land to be granted, the Land Bureau is required to send invitation letters, tendering documents, and other detailed information to all invited bidders; (2) invited bidders must pay a deposit to a designated agency and deposit a sealed tendering letter into the designated tendering box by the specified time and date; (3) experts will be retained and an evaluation committee will be set up by the Land Bureau in conjunction with the other relevant governmental departments. The committee will then review, evaluate, and award the tender to the winning grantee. After the committee signs the determination document, the Land Bureau will issue the certificate to the selected bidder at the address specified on the tendering letter; (4) the selected bidder shall present the certificate, sign a granting contract with the Land Bureau within the specified time period, and pay a further deposit; and (5) finally, the selected bidder must pay the granting fee in accordance with provisions agreed upon in the granting contract and obtain a land-use certificate from the Land Bureau. In addition, the grantee must register the land-use rights in the Municipal Registry within the specified time. ${ }^{73}$

Under the Shanghai Measures, if the selected bidder fails to enter into a granting contract with the Land Bureau within the specified time, its right is terminated and any deposits made up to that time are forfeited. If the selected bidder cannot agree upon the terms of a granting contract with the Land Bureau for proper reason, it can apply to the Land Bureau for an extension period within ten days before the expiration date, which shall not exceed thirty days. The Measures do not specify what "the proper reason" is for not entering into the contract. Nor do they state who will judge and under what guidelines "the proper reason" will be determined if the underlying parties have a dispute on the issue. Since the extension period is limited, time pressure combined with the ambiguity of the regulations will put the grantee in a disadvantageous position in negotiations with the Land Bureau.

After the granting contract is signed, the grantee is obligated to pay the first land-use fee to the grantor. The land-use fee is paid annually by the grantee to the Municipal Government for the privilege of using designated land and is in addition to the one-time granting fee described above.

72. Shanghai Measures, art. 16.

73. Id. art. 17. 
The Shanghai Measures have set certain requirements for the use of land. First, if buildings or other facilities are to be built on the granted land, the grantee shall be responsible for fulfilling all the application and examination procedures in accordance with relevant provisions relating to city management. This includes compliance with the Shanghai City Development Plan and all construction management, building management, transportation, environmental protection, health, sanitation, and fire protection requirements. ${ }^{74}$

Second, if the grantee does not complete the construction work in accordance with the granting contract, the Land Bureau can impose penalties under specific circumstances. These penalties can range from the imposition of a fine to the revocation of the land-use rights without compensation. ${ }^{75}$ This section is evidence of the Chinese commitment to using land-use rights as an incentive to development. If development does not occur as planned, the granted rights can be forfeited.

Third, if the grantee desires to change the nature of the land use and the planning requirement specified under the granting contract, application must be made in advance to the Land Bureau, which shall then submit it to the Planning Bureau for its approval. After the approval is issued, the grantee shall pay in full a revised granting fee in accordance with the Land Bureau's requirements. A new granting contract or a supplementary contract may be entered into and registration of the revised land-use right is required. ${ }^{76}$

The Shanghai Measures have set basic guidelines for the term of years of a granting contract which vary in accordance with the purpose of the use. Land-use rights for entertainment purposes will be granted for a shorter term (twenty years) than land to be used for industrial scientific, technological, hotel, or residential purposes (fifty years).$^{77}$

At the expiration of the first term for land-use rights, the grantee may apply for an extension of the contract, unless the term of the granting contract provides otherwise, or such extension is not permitted under the City Development Plan. If the extension is granted by the Land Bureau, a new granting fee shall be determined and a new contract shall be entered into between the Land Bureau and the grantee.

Finally, the land-use rights revert to the Land Bureau when the granting contract expires. The Land Bureau shall cancel the land-use certificate and notify the Municipal Registry to cancel the registration. The building on the land and other improvements and fixtures shall be returned to the Land Bureau at the same time without compensation to the grantee. ${ }^{78}$ This again resembles the Anglo-American concept of a ground lease, in which at the end

74. Id. art. 24.

75. Id. art. 25.

76. Id. art. 23 .

77. In Hainan Province, the maximum term for certain projects can be 70 years.

78. Shanghai Measures, arı. 41 . 
of the lease term the land, together with the improvements constructed thereon, reverts to the lessor.

In general, if the term of the granting contract has not expired and a default does not exist, the land-use rights will not be taken back. Under special circumstances, however, the Land Bureau has the right, through legal procedures and on the basis of social and public interest, to revoke the landuse rights. In such a case, the grantee shall be reasonably compensated for the loss of the land-use rights. Such compensation for the contract shall be agreed on through consultation between the Land Bureau and the grantee, based on the remaining years under the contract, the nature of the land-use, the value of the building constructed on the land, the value of other improvements, and the granting fee. If the amount of compensation cannot be resolved by negotiation, either party may bring a suit in the people's court for final determination. ${ }^{79}$

Alternatively, if the land-use rights are to be returned prior to the expiration of the granting contract term, the Land Bureau may, through consultation with the grantee, permit the grantee to use the land-use rights on another piece of land in exchange for the early surrender of the granted rights. Upon the determination of the amount of compensation due to the grantee for the early return of land-use rights and the granting fee to be charged for the land-use rights on the exchange land, a settling of accounts between the parties shall be undertaken. The Land Bureau and the grantee shall enter into a new contract for the land-use rights on the exchanged land. 80

\section{B. Assignment of Land-Use Rights}

The land-use rights can be assigned by the grantor by means of donation, sales, and exchange. However, if the improvements to be constructed pursuant to the granting contract are not completed in accordance with the contract, the land-use rights cannot be assigned to a third party. In addition, if the grantee wants to transfer only portions of the land-use rights, it must obtain approval for such a transfer. If the construction on the land has been completed, the improvements so constructed shall be transferred together with the transfer of the land-use rights. The purpose of these provisions is to guarantee that the grantee will fulfill its obligations under the contract and to ensure that the land-use rights will not be transferred in a piecemeal fashion or separately from the improvements made thereon. If the grantee sells the completed building, the land-use rights on the land covered by the building, including any yard and fencing walls, etc., shall be transferred at the same time. If portions of the building are to be transferred to separate owners, each owner shall take the land-use rights in proportion to its ownership of the building. However, the land-use rights on the land improved by the building

79. Id. arts. $42,43$.

80. Id. art. 45 . 
remain conceptually unified, though owned in proportion to the respective ownership interests in the building. ${ }^{81}$ This is similar to the Anglo-American law concept of interests owned in a tenancy in common.

The actual transaction causing the assignment of land-use rights can be conducted inside or outside of China. If the transfer is conducted outside of China, acknowledgement by the notary public of the local country or region, attestation by the diplomatic institution of the local country or region, and attestation by the Chinese embassy or consulate or commercial representative office in that country are required. However, those countries or regions which have no diplomatic relationship with China or have not set up commercial representative offices in China are excluded as places of transfer. As with the land-use right itself, the assignment must be filed with the Municipal Registry where the registration records are made available to the public for examination.

Finally, if any economic disputes arise from a compensated transfer of land-use rights transaction, either party can submit the dispute to a Chinese arbitration institution or other arbitration institution for settlement in accordance with an arbitration clause in the contract or a written arbitration agreement entered into after the dispute arises. ${ }^{82}$

\section{Mortgage}

The most important aspects of the land-use rights legislation for foreign lenders are the sections of such laws permitting the buildings and other improvements together with the land to be used as collateral for a mortgage loan. While in theory a collateral assignment of land-use rights could be granted to a lender to secure a debt, the restrictions surrounding these assignments, including required consent in some cases, makes that alternative less attractive than a mortgage of such rights. In addition, a mortgage is conceptually easier to enforce since it is a registered right subject to a foreclosure-like process.

According to the Shanghai Measures, the grantee of land-use rights and a lender can enter into a mortgage contract, the terms of which must be consistent with the granting contract, under which the land-use rights are granted as collateral. The establishment of a mortgage shall be registered in the Municipal Registry which shall enable the mortgagee to ensure its lien priority for the purposes of compensation in the event of a default. Priority among several mortgagees is determined by the sequence of registration in the Municipal Registry.

The Shanghai Measures have proven attractive to foreign investors. For example, in August 1988, the Land Bureau in Shanghai and a Japanese corporation entered into a granting contract, in which the land-use rights on a piece of land located in the Shanghai Hongqiao Development Area were

81. Id. art. 28 .

82. Id. art. 50 . 
granted to the Japanese corporation. The Japanese corporation paid approximately twenty-eight million dollars as the granting fee for fifty-year land-use rights in order to construct apartments, an office building, and restaurant on the 12,900 meters of granted land. ${ }^{83}$ Despite this example and many more like it, many foreign lenders and developers remain uncertain as to whether enforcement of a mortgage on land-use rights can be satisfactorily accomplished.

In theory at least, the Shanghai Measures provide that if the mortgagor fails to repay the debt due, or the mortgagor declares dissolution or bankruptcy during the mortgage contract period, the mortgagee is entitled to dispose of the collateral in accordance with the provisions of applicable law and the contract itself. ${ }^{84}$ Although the Shanghai Measures stipulate that the mortgagee "is entitled to dispose of the collateral in accordance with the provisions of applicable law," the Measures do not provide a clear legal mechanism for the enforcement of the mortgage, nor do the regulations or laws in other provinces and cities, or existing national laws provide any such mechanisms or guidelines. However, under article 39 the mortgagee is also entitled to dispose of the collateral in accordance with the contract itself. Thus, the parties concerned may include detailed provisions governing disposition of the property in the mortgage contract. A valid contract will be enforced under Chinese contract law.

Where the contract is silent on enforcement procedures, problems remain for a foreign party. As discussed above, arbitration can be elected after a dispute arises, ${ }^{85}$ but if the parties cannot agree on such an approach, the Chinese Foreign Economic Contract Law may apply.

IX

\section{The Foreign Economic Contract LaW}

If disputes arise in the enforcement of a contract for land-use rights and the contract is silent on the disposition of such matter and if Chinese law governs the contract, the Foreign Economic Contract Law of the PRC will act as a framework within which to resolve such a dispute.

The Foreign Economic Contract Law ("FECL"), 86 which went into effect on July 1,1985 , is the first national statute in the PRC that applies solely to

83. See People's Daily, Aug. 9, 1988, at 3. The regulations adopted in Shenzhen on the compensated transfer of land-use rights are similar to those of Shanghai, except for several technical differences. In Hainan, the detailed provisions have not been published, but the general principles have been promulgated. See Provisions of the State Council on Encouraging Investment to Promote the Development of Hainan Island, promulgated by the State Council on May 4, 1988.

Currently, more than 800 business enterprises and investors both from China and abroad have ventured to Hainan to discuss the possibility of obtaining land-use rights for development. See People's Daily, June 11, 1988, at 3.

84. Shanghai Measures, art. 39.

85. Ser supra note 81 and accompanying text; see generally Kui-Nung Chung, Enforcement of Foreign Arbitral tu'urds in the People's Republic of China, 34 Am. J. Comp. L. 295 (1986).

86. The Foreign Economic Contract Law of 1985 (PRC) was adopted at the Tenth Session of the Standing Committee of the Sixth National Congress on Mar. 21,1985 [hereinafter FECL]. It built on 
contracts involving a foreign party. ${ }^{87}$ The FECL applies to economic contracts between enterprises, or other economic institutions of the PRC, and their foreign counterparts or individuals. 88 An "economic contract" is defined as "an agreement between legal persons for achieving a certain economic purpose and for defining each other's rights and obligations." 89 Since the definition of an economic contract is broad enough to encompass the concept of a mortgage or other security interest between a foreign party and a PRC "person," the FECL provides a necessary structure for the enforcement of contractual rights and obligations in the case of land-use rights or a security interest in land.

The FECL states that a contract is formed when the parties reach written agreement on its provisions and when such agreement is approved, if so required under the laws or administrative decrees of the PRC. ${ }^{90}$ The FECL does not specifically address the point at which such written agreement has been reached, though it does state that "international norms" shall apply. ${ }^{91}$ This implicitly suggests that mutual assent will be objectively determined from the circumstances of contract agreement. ${ }^{92}$ Not only must mutual assent be reached, but specific terms of the contract must be agreed to as a condition to contract formation. ${ }^{93}$

Once formed, the parties to a contract subject to the FECL can agree to seek settlement of disputes in accordance with the laws of their choosing or, in the absence of such agreement, with the laws of the country most closely related to the contract. ${ }^{94}$ In the case of a land contract, the laws of the PRC, the situs of the property, will most likely be deemed to apply. Disputes are to be settled in an amicable manner through consultation or through mediation by a third party. If the parties do not desire to enter into consultation or mediation, or such consultation or mediation fails, the parties may submit the case to Chinese or other arbitration bodies, according to the terms of the contract. ${ }^{95}$ In the PRC, the Foreign Economic and Trade Arbitration Commission under the auspices of the China International Chamber of Commerce (formerly the China Council for the Promotion of International Trade) has jurisdiction over disputes in contracts with foreign parties. ${ }^{96}$

The Commission will apply the choice of law specified in the contract in conjunction with its own procedural guidelines. The arbitration incorporates

\footnotetext{
and revised the Shenzhen Foreign Economic Contract Law adopted much earlier but applicable only to the Shenzhen Special Economic Zone.

87. Zhao, A Comparative Study of the Uniform Commercial Code and the Foreign Economic Contract Law of the People's Republic of China, 6 INT'L. Tax \& Bus. Law. 26 (1988).

88. FECL, art. 2.

89. Zhao, supra note 86, at 28 (citing Economic Contract Law, art. 2 (PRC)).

90. FECL, art. 7.

91. Id. art. 5.

92. Zhao, supra note 86 , at 30 .

93. FECL, art. 12.

94. Id. art. 5

95. Id. art. 37

96. Zhao, supra note 86 , at 46
} 
mediation into its proceedings, which is consistent with the Chinese cultural preference for resolving disputes in a non-confrontational manner. If the arbitration results in a settlement, the Commission will issue an award and subsequently dismiss the case. If an arbitration decree is issued, such decision is binding upon the parties and may be enforced by the people's court. ${ }^{97}$ If a resolution to the dispute cannot be reached by arbitration, or if arbitration is not provided for in the contract, the parties may bring their dispute directly to the people's court for review. ${ }^{98}$ Litigation is considered a last resort and is not encouraged by the FECL.

In addition to providing for the ultimate settlement of disputes, the FECL governs the parties' conduct under the contract when disputes first arise. When a party has concrete proof that the other party has failed to fulfill a contract, the non-defaulting party may suspend its performance under the contract, provided that it informs the other party of its action. If the other party provides a guarantee that it will fulfill the contract, the non-defaulting party is required to resume performance of its contractual obligations. 99 The requirement of "concrete proof" stresses the Chinese reluctance to permit suspension of a contract barring certainty of non-performance.

If a breach of the contract actually occurs, the non-breaching party is entitled to compensation for its losses suffered or other remedial measures. ${ }^{100}$ The FECL stipulation that further compensation may be sought when such remedial measures are insufficient does not distinguish between punitive and non-punitive measures. ${ }^{101}$ However, such losses are limited to the losses foreseen at the time of contract execution, ${ }^{102}$ thus effectively restricting the recovery of damages. Similarly, the FECL requires the non-defaulting party to further limit losses by mitigating its damages. ${ }^{103}$

The FECL provides the parties to a contract with the option of agreeing to liquidated damages in their document. The liquidated damages can be in the form of a sum certain or can, in the alternative, be a formula for calculating the amount of compensation for losses. However, if the amount of damages provided in the contract is determined to be too high or too low for the loss caused, either party may seek arbitration or appeal to a court of law to reduce or increase the amount as appropriate. ${ }^{104}$

The FECL is a useful attempt to fill in some of the gaps in Chinese enforcement laws for resolving disputes with foreign enterprises. However, it is by no means a complete solution to the problem. It is rather a first step in the long process of Chinese legal development. It is therefore recommended that parties to contracts in China negotiate documents which are over-

97. Id. at $46-47$.

98. FECL, art. 38

99. Id. art. 17.

100. Id. art. 18.

101. Id.

102. Id. art. 19.

103. Id art. 22.

104. Id. art. 20. 
inclusive and detail-oriented. In effect, the documentation itself should contain the mechanisms and rules that are currently lacking in the statutory law. Such contract terms should be enforceable under Chinese law.

\section{$\mathbf{X}$ \\ Conclusion}

The practice of collateralized lending in China by foreign banks has undergone dramatic changes over the past decade. Starting with simple guarantees of loans, lending practices have evolved to include project finance techniques and mortgages of granted land-use rights. The changing lending techniques are reflective of great changes in Chinese society. From an inward looking nation of state socialists, China has become a developing nation in the fullest sense, encouraging foreign investments of capital and expertise to help vault China into the twenty-first century. Similarly, the Chinese concept of property has been transformed from something owned by the state for the good of the people to something selectively available for use in commerce.

Throughout all of these changes, ties with the past have been stretched but not broken. Real property still cannot be owned by an individual, but it can be granted for up to seventy years for private use. Mining rights are owned by the people, yet foreign corporations are encouraged to guarantee export levels of minerals on a long-term basis. At some point, the line between state and individual ownership begins to blur, and the tie to socialism becomes more tenuous.

China is simultaneously living two lives which respectively have very different principles and ramifications for the future. China is still a socialist country with a strong central government. However, it is also a society that encourages the use of property-based collateral to spur foreign investment. This leads to a seemingly internally contradictory version of Marxism tempered by modern day practicalities. The laws and regulations promulgated to encourage foreign lending reflect this dichotomy. In seeking to serve two masters, these laws manage to serve neither one wholeheartedly.

The statutes regulating guarantees and land-use rights are drafted in broad strokes so they can successfully set out fundamental concepts which seek to encourage foreign investment. Unfortunately, because of such broad drafting, many gaps remain. Guidelines governing decisionmaking by the authorities are at best inadequate and at worst nonexistent. Enforcement mechanisms are stated in theory but not spelled out. Laws stress mediation and negotiation but lack democratic societies' legal safeguards that guarantee equal treatment for the challenging enterprise and the government body in the dispute settlement process.

For foreign lenders, the future holds a clarification of the body of law governing collateralized loans. For Chinese borrowers, it holds the promise of continued inflows of foreign capital. For the time being, however, we suggest that foreign lenders who desire to do business in China do so with their eyes open. We also suggest that they err on the side of overcomplete 
documentation, including detailed enforcement procedures, rather than relying on Chinese law to fill in the gaps.

In fairness, Chinese law is evolving rapidly and will continue to improve in the commercial setting as the new century approaches. With Hong Kong due to become part of China in 1997, one must look ahead with the optimism that the laws will become more complete and that a more comfortable peace will be achieved between socialism and development in China.

$\mathrm{X}$

\section{AFTERWORD}

The researching and writing of this article was completed well before this past summer's democratic protests in Beijing and other cities, which culminated in the happenings in Tiananmen Square. Since that time, it appears that the Government of the PRC has been philosophically retrenching and is currently less likely to encourage foreign investment than previously. We are therefore entering a period of relative uncertainty where it is advisable that potential foreign investors proceed with caution.

Mixed signals are being sent by government officials. While some Western observers feel that "creeping expropriation" through tighter regulation is possible, ${ }^{105}$ China continues to publicize cooperative projects with foreign investors. ${ }^{106}$ In any case, if investors do decide to make financial commitments to projects in China, the laws and regulations discussed in this article will continue to be of major importance and are unlikely to be changed in the near future.

105. After Tiananmen, Ominous Signs on Road to China, Wash. Post, November 5, 1989, at H1, col. 1.

106. The People's Daily carried an article in the wake of pro-democracy demonstrations announcing the signing of a land-use contract on August 8, 1989, between the MGM Corporation (USA) and the Tianjin Land Bureau. The terms and conditions of the contract, included: (1) grant of land-use rights for industrial purposes for 70 years; (2) $5.36 \mathrm{~km} 2$ coverage; (3) location in the Tianjin Economic and Technological Development Area; and (4) granting fee of \$17.42 million. See People's Daily, August 18, 1989, at 3. 


\section{ApPendix}

Measures of Shanghai Municipality on Compensated Transfer of Land-Use Rights (promulgated by Shanghai Municipal Government on November 29, 1987, and translated by Danian Zhang)

\section{CHAPTER ONE General Principles}

Article 1

These Measures are formulated in accordance with the pertinent regulations of the state in order to promote all-around reform, implement the policy of opening to the outside world, reform the land-use system, implement on a trial basis the compensated transfer of land-use rights, and accelerate economic development in Shanghai.

Article 2

The terms used in these Measures are defined as follows: (1) "Compensated transfer of land-use rights" means economic transactions within the realm of the real estate business by means of which the compensated granting of land-use rights and the compensated assigning of land-use rights [to a third party] occur.

(2) "Compensated granting of land-use rights" ("granting") means the granting by the Shanghai Municipal Government ("the Municipal Government") of land-use rights on a specified piece of state-owned land to a grantee for development and business purposes, under the conditions that the location of the land, term of years, purpose of the use, etc., are designated by the Municipal Government, and that the grantee shall pay a granting fee and land-use fee for the land-use rights.

(3) "Assignment of land-use rights" ("assignment") means the subsequent transfer of land-use rights by a grantee [to a third party].

(4) "Granting fee for the land-use rights" ("granting fee") is the amount paid by the grantee to the Municipal Government in order to obtain the land-use rights.

(5) "Land-use fee" is the amount paid annually by the grantee to the Municipal Government for the use of the designated land.

(6) "Grantee of the land-use rights" ("grantee") refers to those enterprises, other economic organizations, or individuals which are entitled to receive land-use rights by way of grant, transfer, or inheritance.

Article 3

The ownership of the land remains with the People's Republic of China during the period of compensated transfer of the land-use rights.

Natural resources, minerals, and other buried or hidden objects under the land are not within the scope of a transfer of land-use rights.

Article 4

Enterprises, other economic organizations, or individuals in countries or regions which do not have diplomatic relations with China or have not set up 
any commercial representative office in China are not qualified to be a grantee under these Measures.

Article 5

The legal rights of the grantee are protected by law.

All activities related to the transfer of land-use rights shall be conducted within the laws and regulations of the People's Republic of China and the relevant provisions of the Shanghai Municipality.

Article 6

The Shanghai Land Administration Bureau ("the Land Bureau") is in charge of the transfer of land-use rights in Shanghai.

Any contract granting land-use rights ("granting contract") shall be entered into between the Land Bureau and the grantee.

Article 7

The Shanghai Real Estate Registry ("the Registry") is vested with the responsibility of handling the registration of all transfers of land-use rights. Registration records shall be available to the public for examination.

Article 8

The maximum term of years for the granting of land-use rights shall be determined by the Land Bureau within the following framework:

(1) land used for entertainment-20 years

(2) land used for industry -40 years

(3) land used for apartment or residence-50 years

(4) land used for hotel, commercial, or office building - 50 years

(5) land used for science and technology, education, culture, and health-50 years

(6) land used for comprehensive or other purposes-50 years

If the proposed term shall exceed the above-mentioned time periods, the Land Bureau shall submit [the granting contract] to the Municipal Government for approval.

Article 9

At the expiration of the granting contract, the grantee may apply for an extension of the contract term unless the terms of the granting contract provide otherwise or such extension is not permitted under the city development plan. The maximum term of years for an extension shall be determined by the Land Bureau pursuant to article 8 of these Measures.

If an extension is granted, a new granting fee shall be determined and a new contract shall be entered into [between the Land Bureau and the grantee].

Article 10

Unless the granting contract provides otherwise, the grantee is permitted to transfer the land-use rights [to a third party] or assign them [to a creditor] as a mortgage. Any transfer or mortgage which is in violation of the provisions of these Measures shall be null and void.

Land-use rights can be inherited. 


\section{Article 11}

If the grantee is a foreign investment enterprise, it shall be entitled to preferential treatment according to pertinent provisions of these Measures, and will not be required to pay a land-use fee under the Measures of LandUse Administration for Sino-Foreign Joint Venture Enterprises in Shanghai. However, if the land-use rights are not obtained by the foreign investment enterprise pursuant to these Measures, it shall be required to pay a land-use administration fee as provided in the Measures of Land-Use Administration for Sino-Foreign Joint Venture Enterprises in Shanghai.

Article 12

For any business activities undertaken on designated land by virtue of land-use rights, the project sponsor shall be responsible for fulfilling all procedural requirements including, but not limited to, filing application, obtaining approvals, making industrial and commercial registration, and registration for payment of taxes in the relevant departments in Shanghai.

\section{CHAPTER TWO Compensated Granting of Land-Use Rights}

\section{Article 13}

The location of land and the terms and conditions of the granting shall be collectively determined by the Land Bureau, Shanghai City Planning and Construction Administrative Bureau ("the Planning Bureau"), and Shanghai Real Estate Administrative Bureau ("the Real Estate Bureau"), and shall be implemented after being approved by the Municipal Government.

Article 14

The Land Bureau may grant land-use rights by means of a bilateral agreement or by invitation of tendered bids.

Article 15

The Land Bureau shall provide the following information and relevant provisions to any prospective land-use rights grantee:

(1) Location, boundary, dimension, and topographic map of the land;

(2) Planned use of the land, term for the completion of the construction project, minimum investment amount required for the construction project, and the dimensions for the footprint of the development project;

(3) Planning requirements with respect to volume proportion, density, and height clearance limits;

(4) Environmental protection, landscaping and shrubbery, sanitation and epidemic prevention, transportation, fire protection, and other requirements;

(5) Existing condition of the city public facilities, construction planning and requirements;

(6) Present condition of the surface of the designated land;

(7) Means and term of years of granting;

(8) Qualification of bidders; 
(9) Place and deadline of tender procedure, requirement, standard of evaluation, and determination of the tender;

(10) Deposit for tender;

(11) Requirement and means of payment of granting fee, economic responsibility of the grantee;

(12) Specific provisions and measures with respect to the grant and transfer;

(13) Copy of the standard granting contract;

(14) Relevant provisions with regard to the sale and management of the building;

(15) Other.

\section{Article 16}

The procedure of granting [land-use rights] by agreement shall be as follows:

(1) The Land Bureau shall provide any prospective land-use rights grantee with necessary information and relevant provisions relating to the designated land.

(2) After obtaining these materials, the prospective grantee shall submit to the Land Bureau within the specified time the land development and construction plan and the documents relating to granting fee and means of payment, etc.

(3) After receiving all the documents under subsection (2), the Land Bureau shall respond to the prospective grantee within 30 days.

(4) After the agreement is reached through consultation, a granting contract shall be entered into between the Land Bureau and the grantee and the grantee shall pay a deposit [to the Land Bureau].

(5) The grantee shall pay the granting fee in accordance with the contract. The grantee shall obtain a land-use certificate from the Land Bureau and register in the Municipal Registry for the land-use rights within the specified time.

\section{Article 17}

The procedure for tendering is as follows:

(1) Pursuant to the specific requirements related to the land to be granted, the Land Bureau shall send invitation letters, tendering documents, and other detailed information to all invited bidders.

(2) Invited bidders shall pay a deposit, which shall not earn interest, to the designated place or unit and deposit a sealed tendering letter into the designated tendering box by the specified time and date.

(3) Experts will be retained and an expert evaluation committee will be set up by the Land Bureau in conjunction with the other relevant governmental departments. The committee will review, evaluate, and award tender.

The committee has the right to decide that a tendering letter is null and void if the tendering letter is made by an unqualified bidder, or if a letter is inconsistent with the provisions in the tendering documents or a tendering letter was delivered after the deadline. 
The committee will evaluate all valid tendering letters and determine the winning bidder. After the committee signs the determination document, the Land Bureau will issue the certificate to the selected bidder by using the address specified on the tendering letter.

The Shanghai Notary Public Office shall participate in the process of opening, evaluating, and determining bids and a notary public letter shall be issued thereby.

(4) The selected bidder shall present the certificate, sign a granting contract with the Land Bureau within the specified time period, and pay a deposit.

(5) The selected bidder shall pay the granting fee according to the provision in the granting contract and shall obtain a land-use certificate from the Land Bureau and register the land-use rights in the Municipal Registry within the specified time.

Article 18

If the selected bidder fails to enter into a granting contract with the Land Bureau within the specified time, his right is terminated and the deposit will not be returned. If the selected bidder cannot complete a granting contract with the Land Bureau for proper reason, it can apply to the Land Bureau for an extension within ten days before the expiration date. But the extension period shall not exceed 30 days.

The deposit paid by the selected bidder can be used as a credit against the granting fee. The deposits paid by the non-selected bidders shall be returned in full to the bidders' indicated addresses within the specified time.

Article 19

The deposit can be used to set off the granting fee. If the grantee fails to perform the granting contract, he has no right to request the return of the deposit. If the Land Bureau fails to perform the granting contract, it shall return double the amount of the deposit to the grantee.

Article 20

The granting contract signed between the Land Bureau and the grantee shall be notarized by the Shanghai Notary Public Office.

Article 21

The granting fee shall be paid in currency specified in the contract. Article 22

The grantee shall pay the land-use fee according to the following standards:

(1) If the granted land is less than or equal to 1000 square meters in area, the grantee shall pay 1000 yuan Renminbi.

(2) If the land is greater than 1000 square meters in area, the grantee shall pay one yuan Renminbi for each square meter.

\section{Article 23}

If the grantee desires to change the nature of the land-use and the planning requirement specified under the granting contract, application must be made in advance to the Land Bureau for its approval. After approval is issued, the grantee shall pay in full the granting fee in accordance with the 
Land Bureau's requirements. A new granting contract or a supplementary contract may be entered into and registration [of the land-use rights in the Municipal Registry] is required.

Article 24

If buildings or other facilities are to be built on the granted land, the grantee shall be responsible for fulfilling all the application and examination procedures in accordance with relevant provisions relating to city management. This includes compliance with the Shanghai City Development Plan and all construction management, building management, transportation, environmental protection, health, environmental sanitation, and fire protection requirements, etc.

Article 25

If the grantee does not complete the construction work in accordance with the granting contract, the Land Bureau can impose penalties under specific circumstances. These penalties can range from the imposition of a fine to the revocation of the land-use rights without compensation.

\section{CHAPTER THREE Transfer of Land-Use Rights}

Article 26

If the improvements to be constructed pursuant to the granting contract are not completed in accordance with the contract, the land-use rights cannot be transferred. Approval must be obtained from the Land Bureau in order to transfer portions of land-use rights.

The improvement on land must be transferred together with the transfer of land-use rights.

Article 27

The land-use rights can be transferred by means of donation, sale, and exchange.

Article 28

When the grantee sells the completed building, the land-use rights on the land covered by the building (including yard, fencing wall, etc.) shall be transferred at the same time. If portions of the building are to be transferred [to separate owners], each owner shall take the land-use rights in proportion to its ownership of the building. However, the land-use rights on the land covered by the building as a whole cannot be separated.

If the building is to be sold in separate parts, the seller shall decide in advance the proportionate land-use rights to be transferred to each purchaser, and shall devise a convention for building use, management, and maintenance in accordance with the requirements of the Building Bureau.

If the building is to be sold before construction, it shall be approved by the Land Bureau.

Article 29

When the land-use rights are transferred or inherited, the rights, obligations, and duties under the granting contract and the registration documents shall be transferred at the same time. 


\section{Article 30}

The transfer of land-use rights can be conducted in China or outside of China. However, those countries or regions which have no diplomatic relationship with China or have not set up commercial representative offices in China are excluded as places of transfer. If the transfer is conducted outside of China, acknowledgment by the notary public of the local country or region, attestation by the diplomatic institution of the local country or region, and attestation by the Chinese embassy or consulate or commercial representative office in that country are needed. If the transfer is conducted within China, it shall be notarized by the Shanghai Notary Public Office or by another notary public office with jurisdiction.

The inheritance of the land-use rights must be notarized by the Shanghai Notary Public Office, except if it has been mediated or decided by a court. Article 31

The transferee of the land-use rights and buildings shall be responsible for complying with transfer procedures of the Land Bureau and the Real Estate Bureau respectively, by presenting legal documents such as the granting contract or inheritance certificate which has been notarized or certified pursuant to article 30 of these Measures to such Bureaus. The transferee shall pay the transfer fee and all taxes. Any transfer undertaken without compliance with the transfer procedure shall be void.

Article 32

In the case of the transfer and inheritance of land-use rights (together with the buildings on the land), the transferee shall register in the Municipal Registry after the transfer contract has been executed or a notary public has acknowledged an inheritance.

Article 33

If the nature and the planning requirement of the land-use under the granting contract shall be changed during the process of the transfer of the land-use rights, the provisions of article 23 shall be followed.

Article 34

If the ownership of the whole enterprise or other economic organization which possesses the land-use rights is to be transferred, the land-use rights will be transferred at the same time. This shall be accomplished in accordance with the relevant provisions of these Measures.

\section{CHAPTER FOUR Mortgage}

\section{Article 35}

The land-use rights, the buildings on the land, and other attached properties can be used as collateral for a mortgage.

The establishment of a mortgage shall be registered in the Municipal Registry. 
Article 36

The rights and duties of the mortgagor and mortgagee must be specified in the mortgage contract. The mortgage contract shall not be inconsistent with the provisions in the granting contract.

Article 37

If a leased building is used as collateral by the mortgagor, the original lease relationship shall not be affected.

Article 38

The mortgagee shall have the priority for purpose of compensation. The priority among several mortgagees shall be determined by the sequence of registration in the Municipal Registry.

Article 39

If the mortgagor fails to repay the debt due or the mortgagor declares dissolution or bankruptcy during the mortgage contract period, the mortgagee is entitled to dispose of the collateral in accordance with the provisions of applicable law and the contract itself.

If the land-use rights, the buildings on the land, and other attached properties are transferred due to the sale of the collateral, the transferee shall obtain the notary public acknowledgment and certificate of attestation in accordance with the provisions in article $\mathbf{3 0}$ of these Measures and shall be responsible for the procedure of transfer and registration in accordance with the provisions in article 31 and article 32.

Article 40

If the mortgage is terminated because of the payment of the debt or other causes, the mortgagor and mortgagee shall register the termination of the mortgage in the Municipal Registry.

\section{CHAPTER FIVE Reversion of Land-Use Rights}

Article 41

At the expiration of the granting contract, the land-use rights for the designated land shall revert to the Land Bureau. The Land Bureau shall cancel the land-use certificate at the same time and notify the Municipal Registration Office to cancel the registration. The buildings on the land and other attachments shall be returned to the Land Bureau at the same time without compensation [to the grantee].

If the granting contract provides that the grantee must remove technical equipment, etc., from the land, the grantee shall remove such equipment in the time specified. Unless the granting contract provides otherwise, nonordinary construction must be demolished and cleared up within the specified time, or, as an alternative the grantee shall pay the costs for demolition and clearing.

Article 42

If the term of the granting contract has not expired, the land-use rights shall not be taken back. Under special circumstances, the Land Bureau has the right to revoke the land-use rights following legal procedures, on the basis 
of social and public interest. The grantee shall be reasonably compensated [in such a case for the loss of the land-use rights].

Six months prior to the date the land-use rights are to be returned, the Land Bureau shall notify the grantee and the public living in the area in which the land in question is located of the reason for the return of the land-use rights, the location of the land, boundary of the land, and date of return of the land. On the date specified in the public notice for the return of the land-use rights, the land-use rights, the buildings located on the land, and other improvements will revert to the Land Bureau.

Article 43

The compensation for return of land-use rights before the expiration of the contract shall be decided by the Land Bureau and the grantee through consultation, based on the remaining years under the contract, the nature of the land-use, the value of the buildings constructed on the land, the value of other improvements, the granting fee, etc.

If the amount of compensation cannot be resolved in consultation, either party can bring a suit in the people's court for final determination. The return of the land-use rights on the date specified in the public notice shall not affect the final determination of the amount of compensation.

Article 44

If the land-use rights are to be returned prior to the expiration of the granting contract term, the Land Bureau may, through consultation with the grantee, permit the grantee to use the land-use rights on another piece of land in exchange for the early surrender of the granted rights. Upon the determination of the amount of compensation due to the grantee for the early return of land-use rights and the granting fee to be charged for the land-use rights on the exchange land, a settling of accounts between the parties shall be undertaken.

The Land Bureau and the grantee shall enter into a new contract for the land-use rights on the exchange land. The grantee shall be responsible for complying with all required registrations and with the procedures for changing the granting certificate.

\section{CHAPTER SIX Taxation}

(omitted)

\section{CHAPTER SEVEN Supplementary Articles}

Article 49

If the grantee is an enterprise or other economic organization within China, the relevant tax provisions with respect to domestic enterprises shall be applied. However, the tax on foreign investment enterprises shall be levied according to the provisions under these Measures.

Article 50

With respect to the economic disputes arising from the compensated transfer of land-use rights, both parties can submit the dispute to a Chinese 
arbitration institution or other arbitration institution for settlement in accordance with an arbitration clause in the contract or a written arbitration agreement reached after the arising of the dispute.

If there is no arbitration clause in the contract, or the parties cannot reach an arbitration agreement independently, either party is entitled to file suit in the people's court for settlement of disputes.

Article 51

These Measures shall be interpreted by the Legal Office of the Municipal Government.

Article 52

Specific provisions on the implementation of these Measures shall be enacted by the Land Bureau and other relevant departments, subject to approval by the Municipal Government.

Article 53

If the Measure is amended in the future, the amendment has no retroactive effect on the contracts signed before the amendment. But if the amendment is preferential to the grantee, the grantee can apply for the preferential treatment, unless the law of the state provides otherwise.

Article 54

These Measures shall come into effect on January 1, 1988. 